\title{
Assessing the Risk of University-Student Driving to enhance Safe and Sustainable Traffic Management: A Logistic Regression and Analytic Hierarchy Approach
}

\author{
Shaik Dawood ABDUL KHADAR*, Mohamed MANSOUR, Saleh ALSULAMY, Saleh ALGHAMDI, Mohamed Rafik QURESHI
}

\begin{abstract}
Road accidents have become more common these days and it is pathetic when the accidents happen due to ignorance. The research objective is focused on university students, creating awareness about road safety and improving a sustainable traffic management scenario in the Kingdom of Saudi Arabia. An analytical hierarchy process and a logistic regression model were used to determine the risk priorities ranking of severity factors based on the comparisons of different driver behaviour factors. A cross-sectional survey was conducted among 3200 university students in Saudi Arabia to evaluate the risk associated with accident factors. The main factors taken for risk analysis were Stability during driving, not adhering to rules, committing human errors, Insufficient Visibility, Facing Vehicles Issues. The model estimation analysis revealed the severity, which was based on the student's behavioural factors as a driver which contributed to the high fatality. It is further proposed to teach an interdisciplinary course on Traffic Management to various university students. The awareness towards traffic sense and safety rules would bring down the accidents rates and help the government to maintain smooth traffic density.
\end{abstract}

Keywords: accidents; analytic hierarchy process; driving behaviour; logistics regression; risk assessment; traffic sustainability

\section{INTRODUCTION}

The transport system plays a significant role in the safety of the journey and improving the nation's economy thus enhancing the sustainable transport management system of any country. An accident-free system is a need for densely populated countries. The public transport facilities are minimal in the Kingdom of Saudi Arabia (KSA). The travelling frequency is high due to scattered cities and villages. Most people including university students rely on their vehicles for their daily travel needs. Almost all University students own a vehicle that facilitates driving to become the most routine activity. Thus, there is a high dependency on personal vehicles which gives rise to the high driving culture. As per the studies conducted by the World health organisation (WHO) for accidents in the year 2018, the road traffic accidents death rate of the KSA reached 9,112 (8.75\% of total deaths) [1]. As per the WHO report, approximately 1.3 million people succumb to death every year on the roads globally, whereas about $20-50$ million sustain non-fatal injuries [2]. KSA was the thirtysecond place in global ranking with an age-adjusted death rate of $34.57 \%$ per 100,000 of population, thus rate of road accidents has risen steadily in recent years, which sums to an average of 19 - death per day [3].

On several occasions the children seated at the back seat were pushed against the dashboard or the windshield with a huge impact, thus there is always a risk of being thrown out of the crashed vehicle [4]. The accompanying children along with the driver in the front seat become victims of road accidents due to driving mistake. The victim children have shown head injury and facial injury of about $38.3 \%$ and $34.8 \%$ respectively [5]. It has been reported that $9.1 \%$ of children were driving the car at the time of the accident, whereas $53.8 \%$ were not fastening the seat belt while sitting in the back seats [6]. In Arabian countries, $3.7 \%$ of Omani parents have the practice of using car seat belts for their children, $65 \%$ of parents from the United Arab Emirates follow seat belt practice strictly [7]. As per the study of Ramishetty et al., 289 parents from the KSA participated in infant safety practices and they observed that only $8 \%$ of them had the practice of using a seat belt for their children [8]. Many participants from Kuwait agreed that they were following habits of keeping their children on their lap while driving. They further found that $41 \%$ of drivers practised these risky habits even though they knew dangerous consequences [9].

Nowadays, due to technological advancement, university students have access to the latest video games, they play online racing car competitions using the latest technology [10]. The university students try to race on roads; serious accidents are caused by them. They also perform dangerous stunts with their friends. It has been seen that they develop the habits of racing in the city roads that have put road safety in danger. The literature review reveals that many accidents were mainly caused by the untrained drivers of the age group of 16 and 36 years who did not follow the driving rules and lacked general safety awareness [11]. More than 300,000 traffic accidents occur in KSA every year [12].Traffic accidents are the major cause of death, disability, and injury which mainly occur in the age group of $16-36$ years and cause the highest health care costs to the government of KSA [4]. Moreover, onefifth of injured victims from various road accidents occupy most of the beds in hospitals, and many of them remain under long-term treatments [4]. It was found that nearly 174 million USA dollars are spent on treating the injured [10].

Many people of KSA consider driving as their main hobby or even sport [9]. Usually, on Holidays at the weekends from Thursdays to Saturday, youth drive harshly along the streets, hence stronger enforcement of speeding laws should be enhanced to control them. One of the recent studies on the attitudes and behaviours towards risky driving among adolescents in Saudi Arabia concludes that nearly $40 \%$ of the students are engaged in risky driving behaviour called Tafheet [8]. Most young people practice drifting, a very dangerous sport that involves driving a vehicle at speeds up to $260 \mathrm{~km} / \mathrm{hr}$, they violate traffic rules, hence must be booked for a traffic rule violation [11]. The racer drives at high speed, ignoring the lane limits and drifting sideways. These driving habits are often practised by the students who are known to drift on the highway. It is a major factor that is undoubtedly linked to serious 
deaths and injuries [13]. It has been found that $90 \%$ of drivers violate traffic rules at least once while driving through the roundabout [14].

The most critical factors which cause a collision is speeding by about $65 \%$ of accidents, human error factors mainly due to sleep factor count to $80 \%$ of fatalities, then $50 \%$ of accidents due to traffic rules violations [15]. The other contributing factors include road and environmental factors which account for $20 \%$ of fatalities [16]. In many parts of the Gulf region, people spent the night-time shopping, relaxing at parks, participate in social gatherings and functions, all this takes place in the evenings or at night, due to high temperatures in day time [11]. So, inadequate sleep puts them in a tiring situation that makes them sleep while driving at high speeds which leads to major accidents [17]. Excessive fatigue is another factor responsible for many accidents in developed countries. Fatigue minimises the driver reflexes and thus leads to decrease of reaction time, misjudgement, total loss of consciousness and confusion in identifying traffic basis information which leads to major collisions and loss of lives [11].

This research work concentrates on the main criteria severity factors of collision like stability during driving (MC1), not adhering to rules (MC2), committing human errors (MC3), insufficient visibility (MC4), facing vehicles (MC5). This research was carried out in KSA. The participants were from various universities in KSA. All the students were informed about the survey and they agreed readily to participate in the questionnaire survey. The findings were very informative to university students to avoid the risk factors which cause accidents. First, the main criteria risk factor was stability during driving, the subcriteria factors which cause major collisions are age factor, distraction, misjudgement, fatigue. The second main criteria factor was not adhering to rules, the sub-criteria were overspeeding, jumping signals, misuse of the oneway path, sudden track change, overtaking without signs. The third main criteria were committing human errors, its sub-criteria were neglecting to wear a seat belt, cell phone usage while driving, and applying wrong brakes. The fourth main criterion was insufficient visibility with subcriteria such as eye defect problems, poor lighting, and strong glare. The fifth main criteria were vehicle issues, sub-criteria were brake fail, steering locked, tyre burst, gear jamming, and airbag failure.

This research is concentrated on enhancing the need for sustainable traffic safety management by creating awareness through a risk assessment of the accidents in KSA. An Analytical Hierarchical Process (AHP) was used to identify risk priority ranking. It is done based on comparisons of the university students' behavioural factors which concern road safety. Then, the severity factors are compared with a Logistic Regression (LR) algorithm to analyze whether the accident was fatal or non-fatal. It is a method practiced for risk assessment [18]. The LR model was framed and designed to analyze the nature of severity; it is a model estimation analysis that contributes to high fatality. In this paper, we used a cross-sectional study approach; $H_{01}$ : university-student driving factors lead to fatal accidents against $H_{11}$ : university-student driving factors do not lead to fatal accidents. Moreover, $H_{02}$ : AHP ranking is different from the LR ranking model against $H_{02}$, there is a difference between the two rankings.

The paper is further organized as follows. Section 1 is the introduction. Section 2 gives a brief research methodology adopted in this research giving AHP methodology whereas section 3 provides the application of AHP in risk assessment of driving behaviour to enhance sustainable traffic safety management. Section 4 describes the risk of Accident Severity using LR. Section 5 gives a brief discussion on the risk assessment analysis. Section 6 provides a conclusion. Based on the review of literature it is revealed that there is no specific study concerning risk severity for the driving behaviour of university students. Further, it is also revealed that there is no ranking of risk severity of collisions factors due to driving behaviours using AHP with LR analysis. Another important research gap is noticed, i.e. that no researcher has strongly motivated or pointed out the importance of teaching traffic rules at the school level or college level. Traffic safety management should be a mandatory subject, as it could improve the driving culture among them. Hence, motivating students to learn this subject is the most contributing factor in our work. This research highlights the severity of collisions when university students lack traffic sense.

\section{MATERIAL AND METHODS}

LR and AHP were the methods used in this study. LR was used to define the most significant influencing factors affecting the accident fatal effect based on the data sources from the general department of traffic (GDT). GDT carries out tasks related to traffic management. The GDT belongs to the Saudi ministry of interiors and the ministry of transportation. The objective was to define and delete outlier's accident cases in addition to refining the accident causes registered in the formal accident reports. The verified LR model was used to rank the accident causes based on the Wald statistic [19]. The AHP approach was used to verify the results of the LR model in a more comprehensive systematic approach. Tab. 1 shows model variables of possible critical factors. The preliminary registered factors affecting accidents were 25 causes. A significance level of 0.05 was used to develop the LR model and a consistency percentage of $10 \%$ was used for the AHP model [20]. SPSS and Expert Choice software were used to accomplish the experimental and analysis efforts.

\subsection{Sample Characteristics and Data Collection}

The governmental database of university student accidents was accessed via the concerning Saudi governmental agencies and sectors in the last two years (1500 records). The records in the database were used to develop the LR model. Hence, a selected sample was personally interviewed with university students who have met with car accidents during the last two years based on formal reports. The study participants provided informed consent, and the study design was conducted according to the ethical principles of various universities governed by the Saudi ministry of education. The participants signed a confidentiality consent form, and the interviews included a 
discussion of the questionnaire's questions; revisions for the questions are adopted for verification purposes. 150 participants are included in developing the AHP model. During the face-to-face interview, a self-administered questionnaire containing 20 closed-ended questions with corresponding yes, or no type of answer was also administered. Appendix highlights Survey Questionnaire. Each participant's accident fatality status is recorded based on formal records.

\section{Table 1 The Model Variables}

\begin{tabular}{|c|c|c|c|}
\hline & & & \\
\hline No. & Variable code & Definition & References \\
\hline 1 & Age factor - C11 & University students due to lack of traffic sense, less driving experience, and ignorance of safety rules. & {$[6,21,22]$} \\
\hline 2 & Distraction - C12 & $\begin{array}{l}\text { Tensions from family issues, immense pressure from surroundings; all these mentioned factors lead to } \\
\text { severe distraction while driving. }\end{array}$ & {$[23-25]$} \\
\hline 3 & Misjudgement - C13 & $\begin{array}{l}\text { The driver assumes wrong judgment in analyzing the final decisions at the time of any emergency, it } \\
\text { happens many times while crossing signals. }\end{array}$ & {$[6,9,26]$} \\
\hline 4 & $\begin{array}{l}\text { Fatigue/drugs/ } \\
\text { Alcohol - C14 }\end{array}$ & $\begin{array}{l}\text { They spent the sleepless night without rest, taking unwanted drugs, drive long journey without breaks, which } \\
\text { makes them tired and even a nick of second microsleep loses vehicle stability, ends in a fatality. }\end{array}$ & $\begin{array}{l}{[3,20,23,27,} \\
28]\end{array}$ \\
\hline 5 & Over speeding - C21 & Vhen speeding, they get less time to think, to decide, lose control of vehicles. & $\begin{array}{l}{[6,24,25,29,} \\
30]\end{array}$ \\
\hline 6 & \begin{tabular}{ll|} 
Jumping signals - \\
C22
\end{tabular} & nd negligence of not knowing $\mathrm{t}$ & {$[16,23,31]$} \\
\hline 7 & $\begin{array}{l}\text { Misuse of one-way } \\
\text { path - C23 }\end{array}$ & $\begin{array}{l}\text { Due to impatience, they use this path as U-turns or short cut which results in major collisions by colliding } \\
\text { against the opposite vehicles. }\end{array}$ & {$[17,32]$} \\
\hline 8 & $\begin{array}{l}\text { Sudden track change } \\
- \text { C24 }\end{array}$ & $\begin{array}{l}\text { Due to heavy traffics jams, builds up tension due to traffic congestion, the sudden realization of any work, } \\
\text { and overacting in the middle of the roads to overtake the front vehicle: }\end{array}$ & {$[33,34,35]$} \\
\hline 9 & $\begin{array}{l}\text { Overtaking without } \\
\text { signs - C25 }\end{array}$ & $\begin{array}{l}\text { Lack of traffic sense, lack of driving experience, impatience due to heavy traffic, unwanted racing thoughts, } \\
\text { some sort of mentality of winning over the front vehicle driver. }\end{array}$ & {$[26,29,31]$} \\
\hline 10 & $\begin{array}{l}\text { Neglecting to wear } \\
\text { the seat belt - C } 31\end{array}$ & $\begin{array}{l}\text { Show negligence in wearing a seat belt, sometimes due to the absence of mind. Moreover, at times, many } \\
\text { forget to buckle the seat belt, which might not have been pinned properly thus also leading to collisions. }\end{array}$ & {$[23,24,29]$} \\
\hline 11 & $\begin{array}{l}\text { Cell phone usage } \\
\text { while driving - C32 }\end{array}$ & $\begin{array}{l}\text { Most of them holding the phone, texting, talking busily, listening to music but at a certain point of time, due } \\
\text { to the vibrations, movements of moving vehicle, they lose grip and drop them down, while picking it, they } \\
\text { get distracted and meet fatal collision. }\end{array}$ & $\begin{array}{l}{[3,10,23,24} \\
33,36,37]\end{array}$ \\
\hline 12 & $\begin{array}{l}\text { Applying wrong } \\
\text { brakes - C33 }\end{array}$ & $\begin{array}{l}\text { When an urgent need arises as an emergency stop, at this mode many tend to apply the wrong brakes and } \\
\text { meet collisions. The mind will be concentrated on front view happenings, so an accidental accelerator is } \\
\text { applied, instead of a stop brake. }\end{array}$ & $\begin{array}{l}{[16,27,38,39} \\
40,41]\end{array}$ \\
\hline 13 & $\begin{array}{l}\text { Eye defect problems } \\
-\mathrm{C} 41\end{array}$ & $\begin{array}{l}\text { Due to long-sightedness, the path will not be visible after a certain distance, maybe due to eye issues or } \\
\text { weakness in eye muscles. Non-visibility may be due to night blindness, the path may not be visible in night } \\
\text { hours, mainly after sunset. Moreover, colour blindness, so not able to recognise traffic colour lights signals. }\end{array}$ & {$[42,36,31]$} \\
\hline 14 & Poor lighting - C42 & $\begin{array}{l}\text { Poor weather conditions like rain, fog, sandstorm, and mist. Another cause might be vehicle headlight } \\
\text { damaged, which blocks the road view. }\end{array}$ & {$[26,21,29]$,} \\
\hline 15 & Strong glare - C43 & $\begin{array}{l}\text { Due to humidity and strong sun rays at peak summer, sometimes opposite vehicle reflection, glare creates } \\
\text { darkness, vague vision, a sight which becomes completely blank for a moment, which diverts the driver } \\
\text { attention to move in the wrong direction. }\end{array}$ & {$[29,33,43,44]$} \\
\hline 16 & Brake fail - C51 & $\begin{array}{l}\text { The critical problem for many fatal collisions, mainly due to poor maintenance, brake shoe wear, brake oil } \\
\text { leakage and lack of experience. }\end{array}$ & {$[33,17,44]$} \\
\hline 17 & Steering locked - C52 & $\begin{array}{l}\text { The sudden movement of the vehicle in the wrong direction and the driver loses total balance and ends in } \\
\text { complete collision. }\end{array}$ & {$[8,45,46]$} \\
\hline 18 & Tyre burst - C53 & $\begin{array}{l}\text { Less air in tires creates more friction causing more pressure on tires so it results in bursting out, due to heat. } \\
\text { Worn out old tires make less grip on the road, poor quality locally branded tires with crakes can be } \\
\text { dangerous. }\end{array}$ & {$[27,30,47]$} \\
\hline 19 & Gear jamming - C54 & $\begin{array}{l}\text { Inadequate lubrication, uneven gear changes due to gear jam, make a change in sudden direction while } \\
\text { moving, malfunction of gear suddenly is another cause of collisions, as driver loses control on vehicles. }\end{array}$ & $\begin{array}{l}{[2,25,29,42,} \\
48]\end{array}$ \\
\hline 20 & Airbag failure - C55 & Malfunction of the airbag, it fails to open at the time of collision. & {$[14,2,21]$} \\
\hline
\end{tabular}

The Analytical Hierarchy Process (AHP) approach focuses on the Multi-Criteria Decision Making (MCDM) technique, applied in handling the incommensurable, debatable, multidimensional, and speculative effects of various decisions [49]. AHP is a multifaceted utility theory and the MCDM technique is intended to resolve complex issues related to road accident severity. The AHP model was built as per the steps described in the previous section. The expert team comprising seven Decision-Makers (DMs) having vast experience of more than five years in traffic safety management were involved in ascertaining the influence of each criterion responsible for safe driving, based on the pairwise comparison.

It is very essential to define the clear-cut objective to derive the influence of linked criteria that influence the objective [16]. Generally, a detailed hierarchy representation of the objective, criteria, sub-criteria and alternatives is constructed [38]. The chosen criteria and sub-criteria are compared to ascertain the influence of each criterion over other criteria using Saaty's scale [50]. A decision matrix was framed accordingly [38]. The priority weights of the elements are identified by computing the maximum values of Eigenvectors [51].The local weights and global weights have been derived using a geometric mean method [50]. The local weights and global weights obtained in this manner are further employed in deriving the final ranking [52]. Based on the feedback received from the DMs, the main criteria have been compared and synthesized to derive the weights. Similar pairwise tables have been formulated and subsequent synthesizing has been carried out to derive the weights of each main criteria and sub-criteria [53]. 


\subsection{Research Methodology}

LR algorithm is preferred to be accurate when the data is discrete compared with conventional regression and mainly aims for best fit; it displays categories with binary values [48]. It is a very easy and convenient method, as it links with output and input variables. Moreover, it identifies a positive or negative direction and whether the collision was a severe fatal one or non-fatal with selected variables in confidence level [19]. The mathematical expressions are demonstrated below. To find out the coefficients among the best most probable outcome it utilizes the maximum likelihood algorithm [54]. Determining the severity of the collision predictive analysis method was used with a random sample of 1500 . To avoid bias data collection a similar number of fatal and non-fatal collision data were analyzed for severity using SPSS v27 [20].

$p($ fatal crash $)=\pi(x)=\frac{e^{g(x)}}{1+e^{g(x)}}$

The fatal crash estimation is taken from Eq. (1), where $g(x)$ represents the selected functional input variables and is given by Eq. (2). Subsequently, the selected probability of non-fatal is estimated using the Eq. (3) and Eq. (4).

$$
\begin{aligned}
& g(x)=\beta_{0}+\beta_{1} x_{1}+\beta_{2} x_{2}+\ldots+\beta_{n} x_{n} \\
& p(\text { non-fatal crash })=1-p(\text { fatal crash }) \\
& p(\text { non-fatal crash })=\pi(x)=\frac{1}{1+e^{g(x)}}
\end{aligned}
$$

\section{RESULTS}

\subsection{Respondent's Profile}

The students from 16 universities were selected to represent most of the geographical domain of the KSA. 200 questionnaires were sent to the university students during Oct. - Dec.,2020. The respondent profile is shown in Tab. 2. The universities that participated in the questionnaire survey were Effat university, Fahad Bin Sultan, Imam Abdulrahman Bin Faisal, Islamic University of Medina, Jazan, King Abdul Aziz, King Khalid, King Saud,Majmaah,Najran, Prince Mohammad, Prince Sultan, Saudi Electronic, Shaqra, Tabuk, Umm Al-Qura. The students participated with more enthusiasm and the survey was done with perfection. Based on the survey most students responded from Prince Mohammad University and Jazan University followed by other universities like Majmaah University, King Abdul Aziz University followed by King Saud University. On the other hand, the students who responded with minimum interest were from Prince Sultan and Imam Abdul RahamanUniversity. Among 3200 questionnaires that were sent, 1586 questionnaires were returned, 86 questionnaires were

\begin{tabular}{|c|c|c|c|c|c|}
\hline University & \multirow{2}{*}{$\begin{array}{c}\text { No of } \\
\text { questionnaires }\end{array}$} & \multicolumn{3}{|c|}{ Age group } & \multirow{2}{*}{ Feedback } \\
\hline Effat & & $18-20$ & $21-23$ & $>23$ & \\
\hline Fahad Bin Sultan & & $\frac{1}{3}$ & $\frac{4}{3}$ & $\frac{1}{2}$ & $\frac{12}{8}$ \\
\hline $\begin{array}{c}\text { Imam Abdulrahman } \\
\text { Bin Faisal }\end{array}$ & 15 & 2 & 1 & 2 & 5 \\
\hline $\begin{array}{c}\text { Islamic University } \\
\text { of Medina }\end{array}$ & 15 & 4 & 3 & 2 & 9 \\
\hline Jazan & 20 & 3 & 3 & 1 & 7 \\
\hline King Abdul Aziz & 25 & 2 & 2 & 2 & 6 \\
\hline King Khalid & 25 & 5 & 3 & 3 & 11 \\
\hline King Saud & 16 & 1 & 3 & 2 & 6 \\
\hline Majmaah & 20 & 6 & 4 & 3 & 13 \\
\hline Najran & 40 & 5 & 5 & 4 & 14 \\
\hline Prince Mohammad & 30 & 4 & 4 & 1 & 9 \\
\hline Prince Sultan & 15 & 2 & 2 & 1 & 5 \\
\hline Saudi Electronic & 20 & 4 & 2 & 5 & 11 \\
\hline Shaqra & 20 & 6 & 4 & 3 & 13 \\
\hline Tabuk & 25 & 5 & 4 & 3 & 12 \\
\hline Umm Al-Qura & 30 & 4 & 3 & 3 & 10 \\
\hline
\end{tabular}
found to be incomplete thus there were 1500 valid questionnaires with a $46.87 \%$ feedback rate.

\subsection{LR results}

This LR model is comparatively faster when compared with other models [29]. It enhances a better outcome from predictor variables which are removed and added, then all the independent categorical variables are taken as dummy variables and thus the insignificant ones are eliminated [55]. Tab. 5 shows the risk severity using Wald statistics of LR.

\begin{tabular}{|c|c|c|c|c|c|c|c|}
\hline $\mathrm{MC}$ & $\mathrm{SC}$ & $\beta$ & $\mathrm{Se}$ & $\begin{array}{c}\text { Wald } \\
\text { Statistic }\end{array}$ & $p$ & $\begin{array}{l}\text { Odd } \\
\text { ratio }\end{array}$ & Rank \\
\hline \multirow{4}{*}{$\mathrm{MC1}$} & $\mathrm{C} 11$ & 1.58 & 0.33 & 7.96 & 0.00 & 1.64 & 7 \\
\hline & $\mathrm{C} 12$ & 1.34 & 0.47 & 11.8 & 0.04 & 1.55 & 9 \\
\hline & $\mathrm{C} 13$ & 1.61 & 0.39 & 52.81 & 0.01 & 5.97 & 1 \\
\hline & $\mathrm{C} 14$ & 1.46 & 0.71 & 25.56 & 0.02 & 3.73 & 2 \\
\hline \multirow{5}{*}{ MC2 } & $\mathrm{C} 21$ & 1.87 & 0.11 & 9.97 & 0.03 & 2.19 & 4 \\
\hline & $\mathrm{C} 22$ & 1.45 & 0.36 & 45.6 & 0.00 & 0.98 & 15 \\
\hline & $\mathrm{C} 23$ & 1.00 & 0.19 & 9.76 & 0.004 & 1.22 & 12 \\
\hline & $\mathrm{C} 24$ & 1.34 & 0.54 & 11.78 & 0.03 & 1.17 & 13 \\
\hline & $\mathrm{C} 25$ & 1.38 & 0.22 & 23.89 & 0.02 & 0.66 & 17 \\
\hline \multirow{3}{*}{ MC3 } & C31 & 1.37 & 0.16 & 48.76 & 0.02 & 1.41 & 8 \\
\hline & $\mathrm{C} 32$ & 1.24 & 0.63 & 19.63 & 0.00 & 2.78 & 3 \\
\hline & $\mathrm{C} 33$ & 0.98 & 0.85 & 21.76 & 0.00 & 1.49 & 10 \\
\hline \multirow{3}{*}{ MC4 } & C41 & 1.64 & 0.29 & 4.65 & 0.03 & 1.84 & 6 \\
\hline & C42 & -0.36 & 0.33 & 11.76 & 0.00 & 0.43 & 19 \\
\hline & $\mathrm{C} 43$ & 1.73 & 0.56 & 17.34 & 0.00 & 1.99 & 5 \\
\hline \multirow{6}{*}{ MC5 } & C51 & 0.89 & 0.47 & 36.87 & 0.00 & 1.38 & 11 \\
\hline & $\mathrm{C} 52$ & 1.54 & 0.75 & 23.65 & 0.03 & 0.78 & 16 \\
\hline & C53 & 0.33 & 0.65 & 9.54 & 0.00 & 0.58 & 18 \\
\hline & C54 & -1.22 & 0.31 & 17.35 & 0.0 & 0.33 & 20 \\
\hline & C55 & 0.48 & 0.12 & 24.55 & 0.00 & 1.00 & 14 \\
\hline & Constant & -3.65 & 0.23 & 124.76 & 0.00 & 0.02 & -- \\
\hline
\end{tabular}

Table 3 Significant Model's Parameters Estimates for Sustainable Traffic Safety Management 3915.11; chi-square $=152.06$. $p$-value $<0.001$.

Wald statistics is widely used to test the significance of individually added coefficients, it is usually compared with a $\chi^{2}$ distribution with 1 degree of freedom [56]. The significance level was 0.05 which indicates a $5 \%$ risk, thus concluding that an association exists, when there is no actual association [55]. If the p-value is less than or equal to the significance level, it is concluded that it is statistically significant between the response variable and the term [57]. Mostly, all the significant ones with $p$-values are less than 0.05 as shown in Tab. 3. The risk of the severity is explained by the magnitude and sign of the coefficient. Here a positive sign with a coefficient $(\beta)$ tends 
to have a higher probability of fatality whereas a negative sign has less likelihood of fatality [58].

\subsection{AHP Results}

The results of overall AHP risk priority rankings are highlighted in Tab. 4. Based on the feedback received from the DMs, the main criteria have been compared and synthesized to derive the weights as shown in Tab. 5. Then, Tab. 6 shows the pairwise comparison of sub-criteria after synthesizing. The results obtained from the synthesizing matrix of main criteria show the risk priority ranking of sub-criteria using AHP and sub-criteria. The main criteria ranking obtained are stability during diving, committing human errors, not adhering to rule, insufficient visibility, and facing vehicle issues. It has been observed that stability during driving is the most critical one, mainly with focus on facing vehicle issues, it has more impact. The vehicle issues may be overcome by adopting a proper maintenance policy [59]. Committing human error is due to the unprofessional approach adopted in driving [60]. The negligence in driving caused by not adhering to rules is another important neglected factor in the main criteria. The lack of proper training and driving knowledge may influence this main criterion [17]. Insufficient visibility depends upon the environment [42].

\begin{tabular}{|c|c|c|c|c|c|}
\hline Criteria & $\begin{array}{l}\text { Criteria } \\
\text { weight }\end{array}$ & Subcriteria & $\begin{array}{c}\text { Local } \\
\text { weights }\end{array}$ & $\begin{array}{c}\text { Global } \\
\text { weights }\end{array}$ & Rank \\
\hline \multirow{4}{*}{ MC1 } & \multirow{4}{*}{0.34} & C11 & 0.20 & 0.06 & 7 \\
\hline & & $\mathrm{C} 12$ & 0.15 & 0.05 & 9 \\
\hline & & $\mathrm{C} 13$ & 0.33 & 0.11 & 1 \\
\hline & & C14 & 0.30 & 0.10 & 2 \\
\hline \multirow{5}{*}{ MC2 } & \multirow{5}{*}{0.18} & $\mathrm{C} 21$ & 0.46 & 0.07 & 4 \\
\hline & & $\mathrm{C} 22$ & 0.14 & 0.02 & 15 \\
\hline & & $\mathrm{C} 23$ & 0.17 & 0.03 & 12 \\
\hline & & $\mathrm{C} 24$ & 0.15 & 0.02 & 13 \\
\hline & & $\mathrm{C} 25$ & 0.11 & 0.02 & 17 \\
\hline \multirow{3}{*}{ MC3 } & \multirow{3}{*}{0.19} & C31 & 0.31 & 0.06 & 8 \\
\hline & & $\mathrm{C} 32$ & 0.49 & 0.09 & 3 \\
\hline & & $\mathrm{C} 33$ & 0.19 & 0.03 & 10 \\
\hline \multirow{3}{*}{ MC4 } & \multirow{3}{*}{0.16} & $\mathrm{C} 41$ & 0.42 & 0.06 & 6 \\
\hline & & $\mathrm{C} 42$ & 0.11 & 0.01 & 19 \\
\hline & & $\mathrm{C} 43$ & 0.41 & 0.07 & 5 \\
\hline \multirow{5}{*}{ MC5 } & \multirow{5}{*}{0.11} & C51 & 0.31 & 0.03 & 11 \\
\hline & & $\mathrm{C} 52$ & 0.19 & 0.02 & 16 \\
\hline & & C53 & 0.17 & 0.02 & 18 \\
\hline & & C54 & 0.09 & 0.01 & 20 \\
\hline & & C55 & 0.22 & 0.02 & 14 \\
\hline
\end{tabular}

Table 5 Synthesis Pairwise Comparison for the Main Criteria

\begin{tabular}{|r|c|c|c|c|c|c|}
\hline Criteria & MC1 & MC2 & MC3 & MC4 & MC5 & Eigenvalue \\
\hline MC1 & 1.00 & 1.59 & 2.08 & 2.62 & 2.32 & 0.34 \\
\hline MC2 & 0.63 & 1.00 & 0.63 & 1.26 & 1.65 & 0.18 \\
\hline MC3 & 0.48 & 1.59 & 1.00 & 0.91 & 1.65 & 0.19 \\
\hline MC4 & 0.38 & 0.79 & 1.10 & 1.00 & 1.59 & 0.16 \\
\hline MC5 & 0.43 & 0.61 & 0.61 & 0.63 & 1.00 & 0.11 \\
\hline
\end{tabular}

Table 6 Synthesis Pairwise Comparison for the Subcriteria

\begin{tabular}{|c|c|c|c|c|c|}
\hline Criteria & C11 & C12 & C13 & C14 & Eigenvalue \\
\hline C11 & 1.00 & 1.00 & 1.00 & 0.50 & 0.20 \\
\hline C12 & 1.00 & 1.00 & 0.50 & 0.38 & 0.15 \\
\hline C13 & 1.00 & 2.00 & 1.00 & 2.00 & 0.33 \\
\hline C14 & 2.00 & 2.62 & 0.50 & 1.00 & 0.30 \\
\hline
\end{tabular}

Similar pairwise tables have been formulated and subsequent synthesizing has been carried out to derive the weights of each main criteria and sub-criteria based on the pairwise comparison.

This factor may be constrained to a specific place responsible in some extreme conditions during a specific period and specific time. It may be avoided by adopting the effective use of environmental warning and adopting electronic gadgets [28]. The results obtained state that all sub-criteria are having similar risk priorities as obtained by AHP.

\section{DISCUSSIONS}

The research objective is focused on university students to create awareness about road safety and to improve a sustainable traffic management scenario in the Kingdom of Saudi Arabia. Based on the review of literature it is revealed that there is no specific study concerning risk severity for the driving behaviour of university students. Further, it is also revealed that there is no ranking of risk severity of collisions factors due to driving behaviours using AHP with LR analysis hence there was a research gap noticed. First, $H_{01}$ : University-student driving factors do not lead to fatal accidents. This research highlights the severity of collisions when university students lack traffic sense. The major contributing factor and main severity factor is $\mathrm{C} 13$, which has $\beta=1.61 ; \mathrm{Se}=0.39$, Wald statistic $52.81, p=0.01$, it has a magnitude of odd ratio 5.97, which creates a very high impact of fatality. When analysed using AHP, C13, of driver ranks topmost risk factor with a local weight 0.33 and global weights 0.11 , as this global weight is more when compared to other factors, it confirms the severity and more fatality. It should be highlighted that odds greater than 1 in this study increase the likelihood that the accident will be fatal [48]. The second severity collision factor is $\mathrm{C} 14$, the coefficient for Fatigue was $\beta=1.46$; $\mathrm{Se}$ $=0.71$, Wald statistic 52.81 and $p=0.02$, it has a magnitude of odd ratio $\operatorname{Exp} \beta=3.73$, which is high and hence high chances of fatality. From AHP analysis, C14 has a local weight of 0.30 and a global weight of 0.10 , which has a high global weight, hence this value alerts of high fatality rate, driving in tiredness, they fall asleep suddenly in just a nick of a second, micro-sleep kills them [3].

The third severity factor is seen as the odd ratio values for the variables with more than 1, pointing out the high risk of fatality. Thus, under this category other collisions factors like $\mathrm{C} 32$ have a high chance of meeting fatality with a coefficient value $\beta$ of 1.24 , Se 0.63 , Wald statistic 19.63 with $p=0.001$, the odds ratio value points to 2.78 , this value alerts of high fatality. The AHP results for $\mathrm{C} 32$, with a global weight of 0.09 is ranked as 3rd risk factor due to high global weight; with 0.49 local weight, this factor lacks complete attention \& concentration, driver's carelessness, and ignorance end in a severe fatality. Likewise, the risk analysis was carried out using the LR and AHP analysis was done with the main variables as stability during driving, not adhering to rules, committing human errors, insufficient visibility, facing vehicles issues. Tab. 7 shows the sub-criteria rank comparison obtained using LR and AHP and compared with past research. 

Analytic Hierarchy Approach

\begin{tabular}{|c|c|c|c|c|c|}
\hline Main criteria weight & Sub criteria rank & \begin{tabular}{|c|} 
LR \\
model
\end{tabular} & AHP model & Regression analysis & AHP analysis \\
\hline \multirow[t]{4}{*}{$\mathrm{MC1}$} & C11 & 3.84 & 3.84 & $4.00[61], 2.28[62], 1.64[63], 1.64[64]$ & $1.00[38], 2.285[65]$ \\
\hline & $\mathrm{C} 12$ & 4.78 & 4.78 & $6.14[58], 4.21[64], 2.80[66]$ & $\begin{array}{c}2.50[67], 8.20[68], 2.92 \\
{[65]}\end{array}$ \\
\hline & $\mathrm{C} 13$ & 1.00 & 1.00 & $1.00[13], 2.28[69], 2.28[64]$ & $1.94[70], 7.75[68]$ \\
\hline & $\mathrm{C} 14$ & 1.47 & 1.47 & $1[54], 10[13], 3.35[64]$ & $1.00[1], 1.90[67]$ \\
\hline \multirow[t]{5}{*}{$\mathrm{MC} 2$} & $\mathrm{C} 21$ & 12.42 & 12.42 & $1.00[71], 2.50[13], 6.78[62], 4.21[64,29,30,31]$ & $\begin{array}{c}1.30[67], 5.50[1], 2.88 \\
{[65]}\end{array}$ \\
\hline & $\mathrm{C} 22$ & 7.63 & 7.63 & $5.50[13], 3.57[62]$ & $\begin{array}{l}2.70[67], 5.50[68], 7.75 \\
{[1], 2.92[65]}\end{array}$ \\
\hline & $\mathrm{C} 23$ & 6.21 & 6.21 & $8.71[58], 9.35[62]$ & $8.50[67], 5.50[1]$ \\
\hline & $\mathrm{C} 24$ & 6.68 & 6.68 & $7.42[58], 10.00[62], 2.92[63,19,20]$ & $\begin{array}{c}.40[67], 1.00[68], 4.37 \\
{[1]}\end{array}$ \\
\hline & $\mathrm{C} 25$ & 8.57 & 8.57 & $7.42[62], 7.42[58]$ & $\begin{array}{c}3.40[67], 1.00[68], 4.37 \\
{[1]}\end{array}$ \\
\hline \multirow{2}{*}{ MC3 } & $\mathrm{C} 32$ & 1.94 & 1.94 & $7.00[13], 1.00[66]$ & $\begin{array}{c}2.12[74], 1.00[1], 1.00 \\
{[65]}\end{array}$ \\
\hline & $\mathrm{C} 33$ & 5.26 & 5.26 & $3.57[58], 3.57[66]$ & $\begin{array}{c}3.70[67], 2.50[16], 2.50 \\
{[1]}\end{array}$ \\
\hline \multirow[t]{3}{*}{ MC4 } & $\mathrm{C} 41$ & 3.36 & 3.36 & $4.85[58], 4.21[63], 3.57[64]$ & $9.05[16], 7.00[1]$ \\
\hline & $\mathrm{C} 42$ & 9.52 & 9.52 & $4.21[62], 5.50[63], 6.14[69]$ & $\begin{array}{c}5.50[67], 3.07[38], 3.36 \\
{[70]}\end{array}$ \\
\hline & $\mathrm{C} 43$ & 2.8 & 2.89 & $3.57[62], 4.45[63]$ & $\begin{array}{c}7.90[67], 5.15[38], 8.57 \\
{[70]}\end{array}$ \\
\hline \multirow[t]{5}{*}{ MC5 } & C51 & 5.73 & 5.73 & $3.57[58], 7.42[62]$ & $6.70[67], 2.50[1]$ \\
\hline & $\mathrm{C} 52$ & 8.10 & 8.10 & $8.71[69]$ & $6.40[67]$ \\
\hline & C53 & 9.05 & 9.05 & $3.57[58], 3.57[63]$ & $5.80[67], 5.87[74]$ \\
\hline & $\mathrm{C} 54$ & 10.00 & 10.00 & $9.35[62], 9.35[5]$ & $4.90[67], 4.00[1]$ \\
\hline & $\mathrm{C} 55$ & 7.15 & 7.15 & $8.07[62], 8.71[55]$ & $3.76[38], 5.50[74]$ \\
\hline
\end{tabular}

The LR model along with the AHP model has significantly highlighted the accidents severity factors.

Moreover, $H_{02}$ : AHP Ranking is different from the LR ranking model against $H_{02}$, there is a difference between the two rankings. Tab. 7 shows the sub-criteria rank averages obtained using LR and AHP. The sub-criteria ranking obtained by past research using AHP and LR was reviewed. It was observed that various researchers used different criteria and ranked them as shown in Tab. 8 . Hence to compare the results of the present research the common scale of 1 - 10 was selected. The past rank was transformed to the new scale of $1-10$ and compared [26]. The transformed rank of various sub-criteria is tabulated in Tab. 8. It is observed that LR average, AHP average and an overall average of $(\mathrm{C} 11)$ is found to be $(1.85,1.64$, 1.77), Similarly, the other sub-criteria of (C12), (C1), (C14), (C21), (C22), ( C23), (C24), (C25), (C31), (C33), (C41), (C42), (C43), (C51), (C52), (C53), (C54) and (C55) as documented in Tab. 8 ranks are aligned as per the severity. The table highlights the critical factors for severity based on the comparison of the results using LR and AHP.

Table 8 Subcriteria Rank Averages Ccomparison with Past Research

\begin{tabular}{|l|c|c|c|c|c|c|c|c|c|c|c|c|}
\hline $\begin{array}{c}\text { Sub- } \\
\text { criteria }\end{array}$ & $\begin{array}{c}\text { LR } \\
\text { model }\end{array}$ & AHP model & \multicolumn{9}{|c|}{ LR } & \multicolumn{3}{c|}{ AHP } & $\begin{array}{c}\text { Overall } \\
\text { Average }\end{array}$ & $\begin{array}{c}\text { LR } \\
\text { Average }\end{array}$ & $\begin{array}{c}\text { AHP } \\
\text { Average }\end{array}$ \\
\hline C11 & 3.84 & 3.84 & - & 2.28 & 1.64 & 1.64 & 1.00 & 2.28 & - & 1.77 & 1.85 & 1.64 \\
\hline C12 & 4.78 & 4.78 & - & 4.21 & 2.80 & - & 2.50 & - & 2.92 & 3.11 & 3.50 & 2.71 \\
\hline C13 & 1.00 & 1.00 & 1.00 & 2.28 & 2.28 & - & 1.94 & - & - & 1.88 & 1.85 & 1.94 \\
\hline C14 & 1.47 & 1.47 & 1.00 & - & 3.35 & - & 1.00 & 1.90 & - & 1.81 & 2.17 & 1.45 \\
\hline C21 & 1.94 & 1.94 & 1.00 & 2.50 & 6.78 & 4.21 & 1.30 & - & 2.88 & 3.11 & 3.62 & 2.09 \\
\hline C22 & 7.63 & 7.63 & 5.50 & 3.57 & - & - & - & 5.50 & 7.75 & 5.58 & 4.53 & 6.62 \\
\hline C23 & 6.21 & 6.21 & 8.71 & 9.35 & - & - & 8.50 & 5.50 & - & 8.01 & 9.03 & 7.00 \\
\hline C24 & 6.68 & 6.68 & 7.42 & 10.0 & - & - & - & - & 4.37 & 7.26 & 8.71 & 4.37 \\
\hline C25 & 8.57 & 8.57 & 7.42 & 7.42 & - & - & - & - & - & 7.42 & 7.42 & - \\
\hline C31 & 4.31 & 4.31 & 7.42 & - & 5.50 & - & 6.25 & 2.89 & - & 5.51 & 6.46 & 4.57 \\
\hline C32 & 1.94 & 1.94 & - & 1.00 & - & - & 2.12 & 1.00 & 1.00 & 1.28 & 1.00 & 1.37 \\
\hline C33 & 5.26 & 5.26 & 3.57 & 3.57 & - & - & 3.70 & 2.50 & 2.50 & 3.16 & 3.57 & 2.90 \\
\hline C41 & 3.36 & 3.36 & 4.85 & 4.21 & 3.57 & - & - & - & - & 4.21 & 4.21 & - \\
\hline C42 & 9.52 & 9.52 & 4.21 & 5.50 & 6.14 & - & 5.50 & - & - & 5.33 & 5.28 & 5.50 \\
\hline C43 & 2.89 & 2.89 & 3.57 & 4.45 & 3.25 & - & - & 5.15 & - & 4.10 & 3.76 & 5.15 \\
\hline C51 & 5.73 & 5.73 & 3.57 & 7.42 & - & - & 6.70 & 2.50 & - & 5.05 & 5.50 & 4.60 \\
\hline C52 & 8.10 & 8.10 & 8.71 & - & - & - & 6.40 & - & - & 7.55 & 8.71 & 6.40 \\
\hline C53 & 9.05 & 9.05 & - & - & - & - & - & - & - & - & - & - \\
\hline C54 & 10.00 & 10.00 & 9.35 & 9.35 & - & - & - & - & - & 9.35 & 9.35 & - \\
\hline C55 & 7.15 & 7.158 & 8.07 & 8.71 & - & - & - & - & - & 8.39 & 8.39 & - \\
\hline
\end{tabular}




\section{CONCLUSION}

It can be concluded that the main response variable which causes accidents is binary (two categories fatal or non-fatal), the LR technique along with AHP was used to develop the model in this study. The main intent was to provide a clear demonstration of a model that can be used to assess critical factors contributing to the severity of traffic accidents. Based on traffic police accident data, twenty explanatory variables were used in the model development process. The results presented in this paper show that the model provided a reasonable statistical fit. The results are highlighted based on the expert drivers' responses to the behaviour questionnaires. The outcomes proved that there is a real need for traffic sense and behavioural importance at the time of the collision. The risk assessment created an awareness of the severity of collisions. The implications of this research work aim to safeguard university students from severe fatality and to create a sustainable smooth traffic scenario. As the main accident contributing factors were found to be the behaviours of the driver, which led to collisions, and by appropriately controlling them, collisions can be minimised.

AHP analysis revealed and ranked the top risky collision behaviour. The LR models were framed and designed to analyse the nature of severity. The model estimation analysis revealed the severity, which was based on the driver behavioural factors which contributed to the high fatality. The positive sign with a coefficient $(\beta)$ tends to have a higher probability of fatality whereas a negative sign has less likelihood of fatality. The research points out that driver's misjudgement is responsible for $80 \%$ of the collisions, which contributed to more collisions. Moreover, youth lack traffic education, ignorance about traffic rules and regulations before they start to drive. This research highlights suggest the drivers, mainly university students, to follow traffic rules and avoid high speeding. From the data of fatalities, drivers should realise the severity of collisions.

The main contribution of this work insists that university students should be taught about traffic road safety rules during school education as most of them begin to drive at an early age. Our research emphasizes importance of introducing Traffic Safety Management subject to be taught to university students. Thus, Traffic Safety management can create more awareness about safety traffic rules and regulation, as this could be the first step to minimise further collisions, which can change the driving culture in the coming years. Hence, this risk assessment research work creates awareness to follow safety while driving through proper traffic rules and points out the catastrophic effects, if not followed properly. The present study has a few limitations. The study reflects the habits and behaviours of Saudi university students. The results may not be generalised for other students as they depend upon many factors like culture, family background, educational level, geographical placement etc. The future analysis can be done using various other factors contributing to road accidents faced by the entire student's community. Multivariate analysis can be applied to analyse the severity along with LR models to analyse the impact of accidents.

\section{Acknowledgments}

The authors acknowledge the Deanship of Scientific Research for proving administrative and financial supports. Funding for this work has been provided by the Deanship of Scientific Research, King Khalid University, and Ministry of Education, Kingdom of Saudi Arabia under (Research Grant Award Number R.G.P.1/221/41). The content is solely the responsibility of the authors and does not necessarily represent the official views of King Khalid University.

\section{Appendix}

Survey questionnaire

\begin{tabular}{|l|l|c|c|}
\hline No. Question & \multicolumn{1}{|c|}{ Agree } & Disagree \\
\hline 1 & Does the age factor lead to fatal accidents & $\square$ & $\square$ \\
\hline 2 & Does distraction lead to fatal accidents & $\square$ & $\square$ \\
\hline 3 & Does misjudgment lead to fatal accidents & $\square$ & $\square$ \\
\hline 4 & Does fatigue lead to fatal accidents & $\square$ & $\square$ \\
\hline 5 & Does over speeding lead to fatal accidents & $\square$ & $\square$ \\
\hline 6 & Does jumping signals lead to fatal accidents & $\square$ & $\square$ \\
\hline 7 & $\begin{array}{l}\text { Does the misuse of the one-way path lead to } \\
\text { fatal accidents }\end{array}$ & $\square$ & $\square$ \\
\hline 8 & $\begin{array}{l}\text { Does sudden track change lead to fatal } \\
\text { accidents }\end{array}$ & $\square$ & $\square$ \\
\hline 9 & $\begin{array}{l}\text { Does overtaking without signs lead to fatal } \\
\text { accidents }\end{array}$ & $\square$ & $\square$ \\
\hline 10 & $\begin{array}{l}\text { Does neglecting to wear a seat belt leads to } \\
\text { fatal accidents }\end{array}$ & $\square$ & $\square$ \\
\hline 11 & $\begin{array}{l}\text { Does cell phone usage while driving lead to } \\
\text { fatal accidents }\end{array}$ & $\square$ & $\square$ \\
\hline 12 & $\begin{array}{l}\text { Does applying wrong brakes lead to fatal } \\
\text { accidents }\end{array}$ & $\square$ & $\square$ \\
\hline 13 & $\begin{array}{l}\text { Does eye defect Problems lead to fatal } \\
\text { accidents }\end{array}$ & $\square$ & $\square$ \\
\hline 14 & Does poor Lighting lead to fatal accidents & $\square$ & $\square$ \\
\hline 15 & Does strong glare lead to fatal accidents & $\square$ & $\square$ \\
\hline 16 & Does brake failure lead to fatal accidents & $\square$ & $\square$ \\
\hline 17 & Does steering lock lead to fatal accidents & $\square$ & $\square$ \\
\hline 18 & Does tire burst lead to fatal accidents & $\square$ & $\square$ \\
\hline 19 & Does gear jam lead to fatal accidents & $\square$ & $\square$ \\
\hline 20 & Does airbag failure lead to fatal accidents & $\square$ & $\square$ \\
\hline & \multicolumn{1}{|c|}{} & $\square$ \\
\hline
\end{tabular}

\section{REFERENCES}

[1] Moslem, S., Farooq, D., Ghorbanzadeh, O., \& Blaschke, T. (2020). Application of the AHP-BWM model for evaluating driver behavior factors related to road safety: A case study for Budapest. Symmetry, 12. https://doi.org/10.3390/sym12020243

[2] Elshambaty, Y., Ahmed, A., Alzahrani, A., Alzahrani, B., Shahwan, W., \& Alffalah, A. (2019). An unusual cause of road traffic accident with an unusual outcome in Saudi Arabia. International Journal of Medicine in Developing Countries, 3, 694-8. https://doi.org/10.24911/ijmdc.51-1550168858

[3] Philip, P., Chaufton, C., Orriols, L., Lagarde, E., Amoros, E., Laumon, B., Torbjorn, A., Jacques, T., \& Patricia, S. (2014). Complaints of poor sleep and risk of traffic accidents: A population-based case-control study. PLoS ONE, 9, 1-14. https://doi.org/10.1371/journal.pone.0114102

[4] Memish, Z. A., Jaber, S., Mokdad, A. H., AlMazroa, M. A., Murray, C. J. L., \& Al Rabeeah, A. A. (2014). Burden of disease, injuries, and risk factors in the Kingdom of Saudi Arabia, 1990-2010. Preventing Chronic Disease, 11, 1-12. https://doi.org/10.5888/pcd11.140176

[5] Hassan, H. M. i\& Al-Faleh, H. (2013). Exploring the risk factors associated with the size and severity of roadway crashes in Riyadh. Journal of Safety Research, Elsevier Ltd. 
47, 67-74. https://doi.org/10.1016/j.jsr.2013.09.002

[6] Alghnam, S., Alrowaily, M., Alkelya, M., Alsaif, A., Almoaiqel, F., \& Aldegheishem, A. (2018). The prevalence of seatbelt and mobile phone use among drivers in Riyadh, Saudi Arabia: An observational study. Journal of Safety Research, Elsevier Ltd and National Safety Council. 66, 337. https://doi.org/10.1016/j.jsr.2018.05.001

[7] Alsanea, M., Masuadi, E., \& Hazwani, T. (2018). Use of child restraint system and patterns of child transportation in Riyadh, Saudi Arabia. PLoS ONE, 13, 1-9. https://doi.org/10.1371/journal.pone.0190471

[8] Ramisetty-Mikler, S. \& Almakadma, A. (2016). Attitudes and behaviors towards risky driving among adolescents in Saudi Arabia. International Journal of Pediatrics and Adolescent Medicine, Elsevier Ltd., 3, 55-63. https://doi.org/10.1016/j.jpam.2016.03.003

[9] Rehman, S. U., Butt, F. M., Ashiq, M., Minhas, K. S., \& Ajmal Khan, M. (2020). Bibliometric analysis of road traffic injuries research in the Gulf Cooperation Council region. F1000 Research, 9 . https://doi.org/10.12688/f1000research.25903.1

[10] Ghaffar, U. B. \& Ahmed, S. (2015). A Review of Road traffic accident in Saudi Arabia: the neglected epidemic. Indian Journal of Forensic and Community Medicine, 2, 242. https://doi.org/10.5958/2394-6776.2015.00010.7

[11] Mansuri, F. A., Al-Zalabani, A. H., Zalat, M. M., \& Qabshawi, R. I. (2015). Road safety and road traffic accidents in Saudi Arabia: A systematic review of existing evidence. Saudi Medical Journal, 36, 418-24. https://doi.org/10.15537/smj.2015.4.10003

[12] Barrimah, I., Midhet, F. i Sharaf, F. (2012). Epidemiology of Road Traffic Injuries in Qassim Region, Saudi Arabia: Consistency of Police Abstract : Road traffic injuries ( RTI ) are a major public health problem worldwide and a major cause of death and disability. Furthermore, according to the $W ., 6,1-12$. https://doi.org/10.12816/0005971

[13] Bener, A., Yildirim, E., Özkan, T., \& Lajunen, T. (2017). Driver sleepiness, fatigue, careless behavior and risk of motor vehicle crash and injury: Population based case and control study. Journal of Traffic and Transportation Engineering (English Edition), 4, 496-502. https://doi.org/10.1016/j.jte.2017.07.005

[14] Delen, D., Tomak, L., Topuz, K., \& Eryarsoy, E. (2017). Investigating injury severity risk factors in automobile crashes with predictive analytics and sensitivity analysis methods. Journal of Transport and Health, Elsevier Ltd., 4, 118-31. https://doi.org/10.1016/j.jth.2017.01.009

[15] Chen, C., Zhang, G., Liu, X.C., Ci, Y., Huang, H., Ma, J., \& ostali. (2016). Driver injury severity outcome analysis in rural interstate highway crashes: a two-level Bayesian logistic regression interpretation. Accident Analysis and Prevention, Elsevier Ltd. 97, 69-78. https://doi.org/10.1016/j.aap.2016.07.031

[16] Farooq, D., Moslem, S. i Duleba, S. (2019). Evaluation of driver behavior criteria for evolution of sustainable traffic safety. Sustainability (Switzerland), 11. https://doi.org/10.3390/su11113142

[17] Rolison, J.J., Regev, S., Moutari, S. i Feeney, A. (2018). What are the factors that contribute to road accidents? An assessment of law enforcement views, ordinary drivers' opinions, and road accident records. Accident Analysis and Prevention, Elsevier., 115, 11-24. https://doi.org/10.1016/j.aap.2018.02.025

[18] Cheng, G., Cheng, R., Zhang, S., \& Sun, X. (2019). Risk evaluation method for highway roadside accidents. Advances in Mechanical Engineering, 11, 1-12. https://doi.org/10.1177/1687814018821743

[19] Yıldız, K. \& Ateş, A.D. (2020). Evaluation of Level Crossing Accident Factors by Logistic Regression Method: A Case Study. Iranian Journal of Science and Technology-
Transactions of Civil Engineering, Springer International Publishing., 44, 1255-1264. https://doi.org/10.1007/s40996-020-00367-z

[20] Mehrara Molan, A., Rezapour, M., \& Ksaibati, K. (2020). Investigating the relationship between crash severity, traffic barrier type, and vehicle type in crashes involving traffic barrier. Journal of Traffic and Transportation Engineering (English Edition), Elsevier Ltd., 7, 125-36. https://doi.org/10.1016/j.jtte.2019.03.004

[21] Shah, S. A. R., Ahmad, N., Shen, Y., Pirdavani, A., Basheer, M. A., \& Brijs, T. (2018). Road safety risk assessment: An analysis of transport policy and management for low-, middle-, and high-income Asian countries. Sustainability (Switzerland), 10. https://doi.org/10.3390/su10020389

[22] Soltanzadeh, A., Mohammadfam, I., Moghimbeygi, A., \& Ghiasvand, R. (2017). Exploring Causal Factors on the Severity Rate of Occupational Accidents in Construction Worksites. International Journal of Civil Engineering, Springer International Publishing., 15, 959-65. https://doi.org/10.1007/s40999-017-0184-9

[23] Abu Abdo, M. A. \& Al-Ibrahim, Y. A. (2016). Assessment of Traffic Safety and Awareness Among Road Users in Salalah, Sultanate of Oman. Research Journal of Applied Sciences, Engineering and Technology, 12, 574-81. https://doi.org/10.19026/rjaset.12.2685

[24] Ratrout, N. T., Chowdhury, S., Gazder, U., \& Rahman, S. M. (2017). Characterization of crash-prone drivers in Saudi Arabia-A multivariate analysis. Case Studies on Transport Policy, World Conference on Transport Research Society, 5, 134-42. https://doi.org/10.1016/j.cstp.2016.11.001

[25] Alahmad, S., Alswilem, A., Alhussain, A., Alotaibi, E., Alshehri, M., Alhussain, S., Alwaeli, A. M (2020). Population perception of the management of road traffic accidents. International Journal of Medicine in Developing Countries, 4, 687-94. https://doi.org/10.24911/ijmdc.51-1577135184

[26] Ashraf, I., Hur, S., Shafiq, M., \& Park, Y. (2019). Catastrophic factors involved in road accidents: Underlying causes and descriptive analysis. PLoS ONE, 14, 1-29. https://doi.org/10.1371/journal.pone.0223473

[27] Alotaibi, A. S. (2018). Density-based clustering for road accident data analysis. International Journal of ADVANCED AND APPLIED SCIENCES, 5, 113-21. https://doi.org/10.21833/ijaas.2018.08.014

[28] Vanlaar, W. \& Yannis, G. (2006). Perception of road accident causes. Accident Analysis and Prevention, 38, 15561. https://doi.org/10.1016/j.aap.2005.08.007

[29] Potoglou, D., Carlucci, F., Cirà, A., \& Restaino, M. (2018). Factors associated with urban non-fatal road-accident severity. International Journal of Injury Control and Safety Promotion, Taylor \& Francis. 25, 303-310. https://doi.org/10.1080/17457300.2018.1431945

[30] Tayeb, A. A. El Pareek, V., \& Araar, A. (2015). Applying Association Rules Mining Algorithms for Traffic Accidents in Dubai. International Journal of Soft Computing and Engineering (IJSCE), 2231-307.

[31] Al-Tit, A. A., Ben Dhaou, I., Albejaidi, F. M., \& Alshitawi, M. S. (2020). Traffic Safety Factors in the Qassim Region of Saudi Arabia. SAGE Open, 10. https://doi.org/10.1177/2158244020919500

[32] Jateikiene, L., Andriejauskas, T., Lingyte, I., \& Jasiuniene, V. (2016). Impact Assessment of Speed Calming Measures on Road Safety. Transportation Research Procedia, 14, 4228-4236. https://doi.org/10.1016/j.trpro.2016.05.394

[33] Abu Abdo, A. M. (2017). Sensitivity analysis of traffic accidents causes in Sultanate of Oman. ARPN Journal of Engineering and Applied Sciences, 12, 3554-60.

[34] Yang, Y., Yuan, Z. Z., Sun, D. Y., \& Wen, X. L. (2019). Analysis of the factors influencing highway crash risk in different regional types based on improved Apriori 
algorithm. Advances in Transportation Studies, 49, 165-78.

[35] Chen, Q., Huang, H., Li, Y., Lee, J., Long, K., Gu, R., Zhai, $X$. (2021). Modeling accident risks in different lanechanging behavioral patterns. Analytic Methods in Accident Research, 30. https://doi.org/10.1016/j.amar.2021.100159

[36] Society, T. R. (2016). Produced with the support of the Department for Transport December 2016.

[37] Cioca, L. I. \& Ivascu, L. (2017). Risk indicators and road accident analysis for the period 2012-2016. Sustainability (Switzerland), 9, 1-15. https://doi.org/10.3390/su9091530

[38] Xi, J., Zhao, Z., Li, W., \& Wang, Q. (2016). A Traffic Accident Causation Analysis Method Based on AHPApriori. Procedia Engineering, Elsevier B.V., 137, 680-7. https://doi.org/10.1016/j.proeng.2016.01.305

[39] Mohamed, M. \& Bromfield, N. F. (2017). Attitudes, driving behavior, and accident involvement among young male drivers in Saudi Arabia. Transportation Research Part F: Traffic Psychology and Behaviour, Elsevier Ltd., 47, 59-71. https://doi.org/10.1016/j.trf.2017.04.009

[40] Road Safety at Work. (2016). Hazard Identification and Risk Assessment Road Safety At Work website content. 1-13.

[41] Lee, Y. (2020). Analysis of unintended acceleration through physical interference of accelerator. Forensic Science International: Reports, Elsevier B.V., 2, 100079. https://doi.org/10.1016/j.fsir.2020.100079

[42] Jackson, T. L. \& Sharif, H. O. (2016). Rainfall impacts on traffic safety: rain-related fatal crashes in Texas. Geomatics, Natural Hazards and Risk, Taylor \& Francis., 7, 843R-60. https://doi.org/10.1080/19475705.2014.984246

[43] Mitra, S. (2014). Sun glare and road safety: An empirical investigation of intersection crashes. Safety Science, Elsevier Ltd., 70, 246-54. https://doi.org/10.1016/j.ssci.2014.06.005

[44] Bhalla, K. \& Gleason, K. (2020). Effects of vehicle safety design on road traffic deaths, injuries, and public health burden in the Latin American region: a modelling study. The Lancet Global Health, 8, 819-828. https://doi.org/10.1016/S2214-109X(20)30102-9

[45] Tavoosi, V., Kazemi, R., \& Hosseini, S. M. (2014). Vehicle handling improvement with steer-by-wire system using hardware in the loop method. Journal of Applied Research and Technology, 12, 769-81. https://doi.org/10.1016/S1665-6423(14)70093-8

[46] Fang, Y., Zhang, Y., Li, N., \& Shang, Y. (2020). Research on a medium-tracked omni-vehicle. Mechanical Sciences, 11, 137-52. https://doi.org/10.5194/ms-11-137-2020

[47] Wang, F., Chen, H., Guo, L., \& Hu, Y. (2018). Predictive safety control for road vehicles after a tire blowout. Science China Information Sciences, 61, 1-3. https://doi.org/10.1007/s11432-017-9330-6

[48] Michalaki, P., Quddus, M. A., Pitfield, D., \& Huetson, A. (2015). Exploring the factors affecting motorway accident severity in England using the generalised ordered logistic regression model. Journal of Safety Research, 55, 89-97. https://doi.org/10.1016/j.jsr.2015.09.004

[49] Baig, R. U., Dawood, S., Mansour, M., \& Tawfeek, T. (2020). Identifying and prioritising future robot control research with multi-criteria decision-making. Transactions of Famena, 44, 23-34. https://doi.org/10.21278/TOF.44302

[50] Saaty, T.L. i Hu, G. (1998). Ranking by eigenvector versus other methods in the analytic hierarchy process. Applied Mathematics Letters, 11, 121-5. https://doi.org/10.1016/S0893-9659(98)00068-8

[51] Vargas, L. G. (1990). An overview of the analytic hierarchy process and its applications. European Journal of Operational Research, 48, 2-8. https://doi.org/10.1016/0377-2217(90)90056-H

[52] Mansour, M., Dawood, S., \& Falqi, I. (2020). An Integrated Structural Equation Modeling and Analtyic Hierarchy process approach to prioritize investment in the construction industry to achieve sustainable development in Saudi Arabia.
Polish Journal of Environmental Studies, 29, 2285-2302. https://doi.org/10.15244/pjoes/110516

[53] Khan, M. S., Mansour, M. A. A., Khadar, S. D. A., \& Mallick, Z. (2020). Evaluating healthcare performance using fuzzy logic [Internet]. South African J. Ind. Eng. https://doi.org/10.7166/31-1-2150

[54] Andijani, S. (2017). Knowledge, attitude, and practice of parents regarding children's car safety seat. International Journal of Medicine in Developing Countries, 1, 46-51. https://doi.org/10.24911/ijmdc.1.2.2

[55] Sun, D. \& Jia, A. (2016). Impacts of cell phone use on driving safety and drivers' perception of risk. Journal of Modern Transportation, Springer Berlin Heidelberg, 24, 145-52. https://doi.org/10.1007/s40534-016-0102-x

[56] Kim, Y. J., Jang, H. M., Lee, Y., Lee, D., \& Kim, D. J. (2018). Effects of internet and Smartphone addictions on depression and anxiety based on propensity score matching analysis. International Journal of Environmental Research and Public Health, 15, 1-10. https://doi.org/10.3390/ijerph15050859

[57] Asare, I. O. \& Mensah, A. C. (2020). Crash severity modelling using ordinal logistic regression approach. International Journal of Injury Control and Safety Promotion, Taylor \& Francis, 27, 1-8. https://doi.org/10.1080/17457300.2020.1790615

[58] Chen, M. M. \& Chen, M. C. (2020). Modeling road accident severity with comparisons of logistic regression, decision tree and random forest. Information (Switzerland), 11. https://doi.org/10.3390//NF011050270

[59] Usman, T., Fu, L., \& Miranda-Moreno, L. F. (2010). Quantifying safety benefit of winter road maintenance: Accident frequency modeling. Accident Analysis and Prevention, Elsevier Ltd., 42, 1878-87. https://doi.org/10.1016/j.aap.2010.05.008

[60] Febres, J. D., García-Herrero, S., Herrera, S., Gutiérrez, J. M., López-García, J. R., \& Mariscal, M. A. (2020). Influence of seat-belt use on the severity of injury in traffic accidents. European Transport Research Review, European Transport Research Review., 12 https://doi.org/10.1186/s12544-020-0401-5

[61] Kriswardhana, W., Sulistyono, S., Ervina, I., Supriyanto, D., Hayati, N. N., Wicaksono, A., Mujanarko, S. W., \& Ramadhani, R. A. (2019). Modeling The Probability Of Speeding Behaviour And Accident Involvement Using Binary Logistic Regression Model Probabilitas Perilaku Speeding dan Keterlibatan Kecelakaan Menggunakan. Journal of Indonesia Road Safety, 2, 149-58. https://doi.org/10.19184/korlantas-jirs.v2i3.15048

[62] Al-Ghamdi, A. S. (2002). Using logistic regression to estimate the influence of accident factors on accident severity. Accident Analysis and Prevention, 34, 729-41. https://doi.org/10.1016/S0001-4575(01)00073-2

[63] Naik, B., Tung, L. W., Zhao, S., \& Khattak, A. J. (2016). Weather impacts on single-vehicle truck crash injury severity. Journal of Safety Research, Elsevier Ltd and National Safety Council., 58, 57-65. https://doi.org/10.1016/j.jsr.2016.06.005

[64] Xi, J., Guo, H., Tian, J., Liu, L., \& Sun, W. (2019). Analysis of influencing factors for rear-end collision on the freeway. Advances in Mechanical Engineering, 11, 1-10. https://doi.org/10.1177/1687814019865079

[65] Alshammari, M., Abo El-Fetoh, N., Alshammari, M., Alshammari, A., Alsharari, A., Alshammari, O., Alshammari Y. N., Alshammari, A. Z., Alshammari A. K, Alenezi, O. T. M., \& Alanazi, A. B. (2017). A study on road traffic accidents in Arar, Saudi Arabia. The Egyptian Journal of Surgery, 36, 451. https://doi.org/10.4103/ejs.ejs_81_17

[66] Alghnam, S., Towhari, J., Alkelya, M., Alsaif, A., Alrowaily, M., Alrabeeah, F., \& Albabtain, I. (2019). The association between mobile phone use and severe traffic injuries: A case- 
control study from Saudi Arabia. International Journal of Environmental Research and Public Health, 16. https://doi.org/10.3390/ijerph16152706

[67] Sordyl, J. (2015). Application of the AHP method to analyze the significance of the factors affecting road traffic safety. Transport Problems, 10, 57-68. https://doi.org/10.21307/tp-2015-020

[68] Fernandez, J. J., Paringit, M. C., Salvador, J. R., Lucero, P. I., \& Galupino, J. G. (2020). Driver's Road Accident Factor Prioritization using AHP in Relation to Mastery of Traffic Signs in the City of Manila. Transportation Research Procedia, Elsevier B.V. 48, 1316-24. https://doi.org/10.1016/j.trpro.2020.08.158

[69] Penmetsa, P., Pulugurtha, S. S., \& Duddu, V. R. (2018). Factors associated with crashes due to overcorrection or oversteering of vehicles. IATSS Research, International Association of Traffic and Safety Sciences. 42, 24-29. https://doi.org/10.1016/j.iatssr.2017.06.001

[70] Chen, T., Zhang, C., \& Xu, L. (2016). Factor analysis of fatal road traffic crashes with massive casualties in China. Advances in Mechanical Engineering, 8, 1-11. https://doi.org/10.1177/1687814016642712

[71] Abegaz, T., Berhane, Y., Worku, A., Assrat, A., \& Assefa, A. (2014). Effects of excessive speeding and falling asleep while driving on crash injury severity in Ethiopia: A generalized ordered logit model analysis. Accident Analysis and Prevention, Elsevier Ltd., 71, 15-21. https://doi.org/10.1016/j.aap.2014.05.003

[72] Abbas, A.K., Hefny, A.F. i Abu-Zidan, F.M. (2011). Seatbelts and road traffic collision injuries. World Journal of Emergency Surgery, 6, 1-6. https://doi.org/10.1186/1749-7922-6-18

[73] Ng, C.P., Law, T.H., Wong, S.V. i Kulanthaya, S. (2013). Factors related to seatbelt-wearing among rear-seat passengers in Malaysia. Accident Analysis and Prevention, Elsevier Ltd., 50, 351-360. https://doi.org/10.1016/j.aap.2012.05.004

[74] Safari, M., Shamseddin, S., Sadeghi, H., \& Aliashrafi, A. (2020). The priority setting of factors affecting a crash severity using the Analytic Network Process. Journal of Injury and Violence Research, 12, 11-9. https://doi.org/10.5249/jivr.v12i1.1229

Contact information:

\section{Shaik Dawood ADUL KHADAR}

(Corresponding author)

Industrial Engineering Department, College of Engineering,

King Khalid University Abha, Saudi Arabia

E-mail: shdawood@kku.edu.sa

\section{Mohamed MANSOUR}

Industrial Engineering Department, College of Engineering, King Khalid University Abha, Saudi Arabia

Industrial Engineering Department, College of Engineering,

Zagazig University, Zagazig, Egypt

E-mail: momansor@kku.edu.sa

\section{Saleh ALSULAMY}

Architecture and Planning Engineering Department, College of Engineering, King Khalid University, Abha, Saudi Arabia

E-mail: s.alsulamy@kku.edu.sa

\section{Saleh ALGHAMDI}

Industrial Engineering Department, College of Engineering,

King Khalid University Abha, Saudi Arabia

E-mail: syalghamdi@kku.edu.sa

\section{Mohamed Rafik QURESHI}

Industrial Engineering Department, College of Engineering, King Khalid University Abha, Saudi Arabia 